\title{
PENERAPAN INTERNET MARKETING DALAM MENINGKATKAN PENDAPATAN PADA UMKM
}

\author{
INTERNET MARKETING IMPLEMENTATION \\ TO INCREASE MSMES REVENUE
}

\author{
${ }^{1)}$ Dedy Harto, ${ }^{2}$ Sulistya Rini Pratiwi, ${ }^{3)}$ Mohamad Nur Utomo, ${ }^{4}$ Meylin Rahmawati \\ ${ }^{1}$ Fakultas Teknik Universitas Borneo Tarakan, Indonesia \\ ${ }^{2,3,4}$ Fakultas Ekonomi Universitas Borneo Tarakan, Indonesia \\ J1. Amal Lama No 1 Tarakan, Kalimantan Utara, Indonesia \\ Email: miss.rainy@ymail.com
}

\begin{abstract}
ABSTRAK
Usaha Mikro Kecil dan Menengah mempunyai peranan yang cukup besar bagi kesejahteraan masyarakat. Sector ini mampu menyerap tenaga kerja cukup besar dan memberi peluang bagi UMKM untuk berkembang dan bersaing dengan perusahaan yang lebih cenderung menggunakan modal besar (capital intensive). Tujuan kegiatan ini adalah memperbaiki aspek manajemen pemasaran yang berdampak pada peningkatan penjualan. Mitra kegiatan ini adalah Kelompok Usaha Makanan Ringan di Kota Tarakan meliputi Usaha Mikro Bude Ramdan Usaha Mikro Ar-Raihan. Permasalahan utama kedua mitra adalah mitra tidak terlalu fokus pada pengelolaan pemasaran lebih mengandalkan system pemasaran yang masih konvensional seperti system pemesanan barang, penitipan pada toko terdekat, serta penjualan di toko sendiri yang posisinya tidak terlalu strategis sehingga menyebabkan penjualan produk yang stagnan. Permasalahan mitra diatasi melalui penerapan manajemen dan teknik pemasaran produk mitra dengan menggunakan media internet (online). Berdasarkan hasil kegiatan diperoleh: 1) terdapat peningkatan pemahaman pentingnya teknologi terhadap usaha; 2) meningkatnya kemampuan dalam pengelolaan teknologi internet; 3) peningkatan dalam penyerapan pasar; 4) Peningkatan kemampuan komunikasi bagi mitra dalam mengelola website dan Social Media Marketing, yaitu kemampuan mitra mengkomunikasikan produk dan merk produk sehingga memiliki daftar pelanggan tetap pada website yang berpotensi melakukan pembelian produk secara berkelanjutan
\end{abstract}

Kata kunci : Aspek Pemasaran, Manajemen Bisnis, Pendekatan Teknologi, UMKM

\section{ABSTRACT}

Micro Small and Medium Enterprises have a significant role in the welfare of the community. The Sector is able to absorb a large enough workforce and provide opportunities for MSMEs to grow and compete with companies that are more likely to use large capital (capital intensive). The purpose of this activity is to improve the aspects of marketing management that impact on increased sales. Partners of this activity are the Group of Snack Food Business In Tarakan City includes Bude Ram Micro Business and Ar-Raihan Micro Business. The main problem of the two partners is that the partners are not very focused on marketing management more relies on the conventional marketing system such as goods ordering system, nearest store care, and sales in its own store which position is not too strategic, causing stagnant product sales. Partner problems accomplished with apply the management and marketing techniques of partner products by using the internet (online) media. Based on the results of activities obtained: 1) there is increasing understanding of the importance of technology to the business; 2) increasing ability in internet technology management; 3) improvement in market absorption; 4) Improved communication skills for partners in managing websites and Social Media Marketing, ie the ability of partners to communicate products and product brands to have a list of regular customers on a website that has the potential to make a sustainable product purchase.

Keywords: Marketing Aspect, Business Management, Technology Approach, MSMEs. 


\section{PENDAHULUAN}

Sejak tahun 1983, pemerintah secara konsisten telah melakukan berbagai upaya deregulasi upaya penyesuaian struktural dan restrukturisasi perekonomian (Kuncoro, 2007). Namun demikian, banyak yang mensinyalir di bidang perdagangan dan investasi tidak memberikan banyak keuntungan bagi perusahaan kecil dan menengah, bahkan justru perusahaan besar dan konglomeratlah yang mendapatkan keuntungan. Studi empiris membuktikan bahwa pertambahan nilai tambah ternyata tidak dinikmati oleh perusahaan skala kecil, sedang dan besar, tetapi justru perusahaan skala konglomerat dengan tenaga kerja lebih dari 1000 orang yang menikmati kenaikan nilai tambah secara absolut maupun per rata-rata perusahaan (Kuncoro \& Abimanyu, 1995).

Di sisi lain, Sektor Usaha Mikro Kecil dan Menengah (UMKM) ini mampu menyerap tenaga kerja cukup besar dan memberi peluang bagi UMKM untuk berkembang dan bersaing dengan perusahaan yang lebih cenderung menggunakan modal besar (capital intensive). Eksistensi UMKM memang tidak dapat diragukan lagi karena terbukti mampu bertahan dan menjadi roda penggerak ekonomi, terutama pasca krisis ekonomi. Disisi lain, UMKM juga menghadapi banyak sekali permasalahan, yaitu terbatasnya modal kerja, Sumber Daya Manusia yang rendah, dan minimnya penguasaan ilmu pengetahuan serta teknologi (Sudaryanto \& Hanim, 2002).

Mitra dalam kegiatan ini adalah Kelompok Usaha Makanan Ringan di Kota Tarakan meliputi Usaha Mikro Bude Ramdan Usaha Mikro Ar-Raihan.

Pemilik Usaha Mikro Bude Ram adalah Ibu Siti Ramlah yang terletak di Jl.Gunung Amal Rt 10 No 25 Kampung Enam Tarakan. Usaha ini didirikan sejak tahun 1982 dan bergerak pada bidang usaha makanan ringan. Jenis makanan ringan yang dihasilkan seperti madu mongso, krupuk, brownies dan kue tradisional lainnya. Usaha Mikro Bude Ram,saat ini telah memiliki ijin usaha yang meliputi :

1. Sertifikat Produksi Pangan Industri Rumah Tangga dari Pemerintah Kota Tarakan Dinas Kesehatan (P-IRT NO. 2156473030050-19).

\section{Sertifikat Halal dari Majelis Ulama} Indonesia NO 10120007160415.

Produk olahan makanan ringan tersebut dijual dalam bentuk sudah siap saji dengan merek "Bude Ram". Dikemas dan dibuat dalam bentuk berbeda-beda. Sejak tahun 2000 sampai saat ini $\mathrm{Bu}$ Siti menambahkan produk olahannya, yaitu dengan menerima katering makanan. UMKM Bude Ram melayani meliputi rantangan untuk rumah tangga, pesanan prasmanan untuk arisan/pengajian, pesanan nasi boks untuk 20-100 porsi, dan pesanan nasi tumpeng.

Dari sisi manajemen pemasaran, menurut Ibu Siti Pemilik Usaha Mikro Bude Ram: "Hasil produksi selama ini dijual di Toko sendiri, dititipkan di Toko sekitar dan produksi berdasarkan pesanan, hanya mengandalkan pemasaran yang konvensional dan hanya menjangkau pelanggan di pasar lokal saja, sehingga omset penjualan tidak terdongkrak dengan biaya produksi semakin meningkat". Ibu Siti mengharapkan pengembangan usaha yang dimiliki, dimana produksinya bisa menjangkau pasar global, minimal mampu menyuplai permintaan dari luar kota. Sementara ini untuk mendukung kemampuan memasarkan produksi produk tersebut disamping kualitas produknya baik,juga diperlukan memilki kemampuan loby dan memahami administrasi yang baik (membuat MOU dan lain-lain). 
Selanjutnya pemilik Usaha Mikro ArRaihan adalah Ibu Euis Mulyati yang terletak di Pantai Amal Baru RT 05 Gang Polmas No 22 Kecamatan Tarakan Timur.Usaha ini didirikan sejak tahun 2011 dan bergerak pada bidang usaha makanan ringan olahan rumput laut. Jenis makanan ringan yang dihasilkan meliputi : Dodol Rumput Laut, Brownies Rumput Laut, Pilus Rumput Laut dan Amplang Rumput Laut. Usaha Mikro ArRaihan,saat ini telah memilki ijin usaha yang meliputi:

1. Surat Izin Usaha Mikro dan Kecil dari Pemerintah Kota Tarakan Kecamatan Tarakan Timur (Nomor: IUMK / 0136 / CTT / 2016)

2. Sertifikat Produksi Pangan Industri Rumah Tangga dari Pemerintah Kota Tarakan Dinas Kesehatan (P-IRT NO. 2046473010002-18)

3. Sertifikat Halal dari Majelis Ulama Indonesia NO 10150005040613

Bahan baku utama keseluruhan produk tersebut adalah rumput laut, tepung dan bumbu-bumbu, namun perbedaan yang mendasar dari produk Usaha Mikro Ar-Raihan adalah penggunaan jenis tepung pada masingmasing produk olahan. Produk ol a h a n rumput laut tersebut dijual dalam bentuk kemasan siap saji, dengan merek"Ar-Raihan"yang dikemas dengan berat bervariasi.

Dari aspek produksi usaha mikro Ar-Raihan menggunakan bahan utama yang digunakan rumput laut, ikan bandeng dan ikan bulan-bulan hasil produksi tambak yang ada disekitar usaha (Kelurahan Pantai Amal). Kondisi ikan dan rumput laut masih segar dan harganya relative murah. Untuk tenaga kerja banyak menggunakan tenaga ibu rumah tangga sekitar, sehingga tenaga kerja yang dibutuhkan mudah direkrut. Hal ini juga relevan dengan program pemerintah yakni untuk memberdayakan ekonomi kerakyatan dengan lebih mengutamakan sumberdaya lokal.

Pokok masalah yang di hadapi mitra belum dapat memahami dan membedakan antara pemasaran dan penjualan. Mitra belum memahami bagaimana membangun sebuah "brand" yang akhirnya akan menciptakan penjualan. Brand dapat dibangun melalui pemasaran. Karena pemasaran bertujuan menghasilkan pelanggan yang mengenal brand dari produk tersebut sehingga menciptakan penjualan secara berkelanjutan (Kotler \& College, 2009). Jadi dengan membangun brand akan mendapatkan pelanggan dan memetik omset dari pelanggan tersebut. Untuk membangun brand maka strategi yang dilakukan adalah dengan mengkomunikasikan pemasaran produk terhadap pelanggan melalui periklanan, promosi penjualan, public relation, personal selling dan direct marketing (Kotler \& College, 2009).

Beberapa studi menunjukkan keefektifan media internet sebagai media pemasaran. Salah satu jenis pemasaran yang memanfaatkan media yang ada di Internet adalah viral marketing atau pemasaran viral. Pemasaran viral adalah model pemasaran dari mulut ke mulut dengan menggunakan media Internet atau Internet Word of Mouth.Viral berati virus yang penyebarannya berlangsung dengan cepat. Di internet, viral marketing adalah teknik pemasaran yang menginduksi pada web situs atau pengguna internet untuk menyampaikan pesan pemasaran ke situs lain atau pengguna internet, yang berpotensi menciptakan pertumbuhan penjualan (seperti virus) yang cepat melalui pesan tersebut (Datta, et all, 2005). Teknologi internet dapat dimanfaatkan dalam manajemen usaha kecil, baik untuk kepentingan bisnis dan kepentingan pemangku lainnya dalam memberdayakan usaha kecil, dalam bentuk portal $e$ marketing yang dikelola oleh instansi pemerintah dan asosiasi usaha kecil 
(Mujiyana et al., 2012). Selanjutnya pemasaran melalui internet seperti email marketing memberikan manfaat dan kemudahan bagi para pelanggan yang mengunakan sistem belanja online dan secara positif mempengaruhi minat pelanggan online untuk berbelanja pada produk yang ditawarkan (Reimers et al., 2016).

Program ini difokuskan pada bagaimana mitra bisa menjalankan manajemen dan teknik pemasaran berbasis internet hanya pada 2 dari 8 jenis internet marketing sebagaimana yang di uraikan di atas yaitu Sistem pemasaran dengan Search Engine Marketing atau SEM dan Social Media Marketing. Penggunaan 2 jenis marketing tersebut didasarkan pada penelitian menunjukkan bahwa kekuatan dalam pemasaran berbasis internet salah satunya terletak pada website yang terklasifikasi dengan baik dan media sosial yang dijalankan (Yulianto, 2015). Kemudian selain itu penerapan internet marketing dengan website (SEM) dan media sosial dirasakan lebih efektif dan mudah dijalankan bagi kedua mitra.

\section{METODE}

Metode yang digunakan adalah transfer ilmu pengetahuan kepada mitra melalui pelatihan dan pendampingan. Pendampingan dan pelatihan dilakukan dimulai dengan memberikan pengetahuan dan pemahaman dasar-dasar internet marketing hingga sampai mitra mampu melakukan pengelolaan toko onlinenya secara berkelanjutan. Diharapkan mitra akan memperoleh nilai tambah dari toko onlinenya tersebut seperti memiliki daftar pelanggan tetap yang membeli produknya baik konsumen yang berasal dari pasar lokal, nasional maupun pasar internasional HASIL DAN PEMBAHASAN

Sosialisasi Internet Marketing Dan Penerapannya
Sosialisasi dilakukan untuk mengedukasi mitra terkait sistem pemasaran yang lebih mudah dan modern. Selain itu, untuk mengetahui seberapa besar pengetahuan mitra tentang penerapan teknologi dalam pemasaran. Sosialisasi meliputi informasi pentingnya teknologi internet untuk mendukung bisnis, bagaimana mengakses teknologi internet (search engine marketing website dan social media), bagaimana berkomunikasi dan mencari informasi dengan media internet.

Kegiatan sosialisasi dapat meningkatkan pengetahuan mitra tentang internet marketing dan penerapannya (Grafik 1).

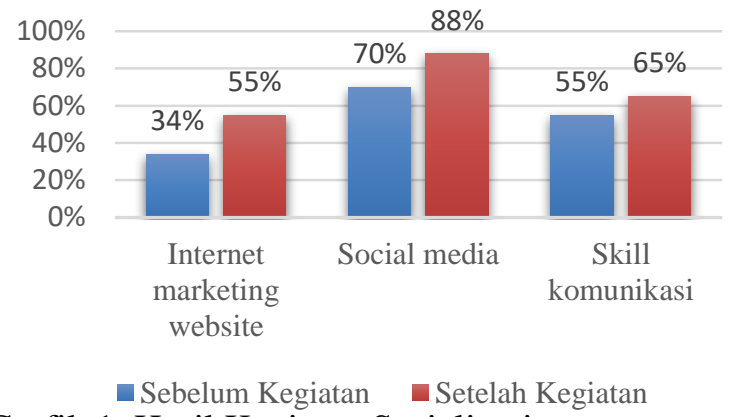

Grafik 1. Hasil Kegiatan Sosialisasi

Kepada Mitra

Berdasarkan hasil observasi, pengetahuan dalam penerapan sosial media lebih tinggi dari pada pengetahuan tentang website, terutama pada media sosial facebook. Adapun kesulitan mitra dalam sosial media instagram, didominasi oleh penggunaan fitur highlight dan story. Peningkatan pengetahuan tertinggi, ada pada informasi internet marketing website, yaitu meningkat sebesar $21 \%$. Internet bisa menjadi wadah kreativitas dan inovasi bagi pengguna. Selain itu, kecanggihan informasi internet sangat membantu pebisnis dalam mengembangkan usahanya (Supriyanto, 2004 ; Kosasi, 2014).

Pelatihan dan Pendampingan Penerapan Internet Marketing 
Pelaksanaan kegiatan diawali dengan koordinasi dengan kelompok mitra. Identifikasi untuk rancangan design website bisnis online dan akun sosial media dari masing-masing usaha mitra. Persiapan design ini akan mewujudkan sebuah website dan akun media sosial yang berfungsi sebagai toko online bagi mitra. Pada pelaksanaan kegiatan pendampingan dilakukan pendampingan dan pelatihan pada mitra untuk dapat mengoperasionalkan website serta akunakun sosial media yang telah dibuat. Pendampingan dan pelatihan dilakukan dimulai dengan memberikan pengetahuan dan pemahaman dasar-dasar internet marketing hingga sampai mitra mampu melakukan pengelolaan toko onlinenya secara berkelanjutan.

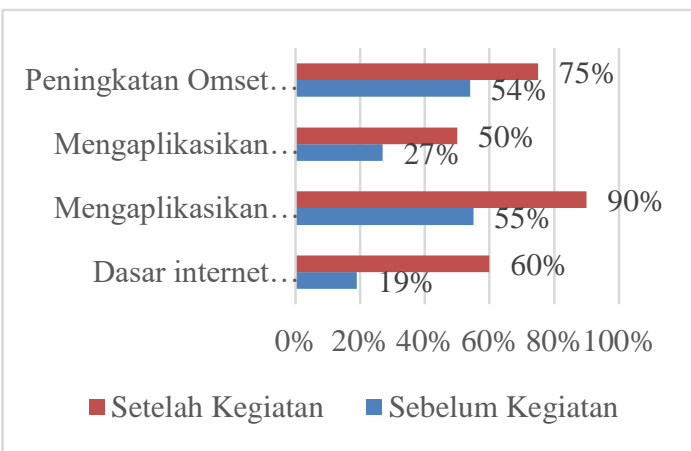

Grafik 2. Rekapitulasi Peningkatan Pemahaman dan Kemampuan Mitra

Berdasarkan hasil evaluasi kegiatan, peningkatan pengetahuan mitra terbesar ada pada pengetahuan dasar internet marketing, yaitu sebesar $41 \%$ (yang semula pemahaman mitra sebesar 19\%, meningkat ke $60 \%$ ). Kemudahan yang diperoleh dan pentingnya memahami dasar-dasar internet marketing, memaksa mitra untuk cepat memahami materi. Peningkatan dan pemahaman berikutnya, diikuti oleh materi pengaplikasian search engine marketing, yaitu sebesar $35 \%$. Menurut mitra, mempelajari internet marketing dengan metode praktek lebih mudah dimengerti dan diingat. Hal ini menyebabkan mitra lebih cepat paham dengan materi yang diberikan. Dari semua materi yang diberikan, mitra kesulitan dalam aplikasi website. Namun demikian terdapat peningkatan pemahaman sebesar $23 \%$.

Dampak kegiatan secara kongkret terhadap masing-masing mitra adalah adanya peningkatan omset usaha. Walaupun tidak signifikan, namun telah terjadi perluasan usaha mitra ke daerah lain selain Kota Tarakan. Mitra juga mendapatkan kemudahan dari akses website dan sosial media. Adanya penerapan teknologi, mitra memperoleh nilai tambah dari toko onlinenya tersebut seperti memiliki daftar pelanggan tetap yang membeli produknya baik konsumen yang berasal dari pasar lokal, nasional maupun pasar internasional (Sagan \& Leighton, 2010).

\section{Website dan Sosial Media Usaha}

$\begin{array}{rrr}\text { Dengan } & \text { memperbaiki } & \text { aspek } \\ \text { manajemen } & \text { pemasaran } & \text { akan }\end{array}$
meningkatkan jumlah pelanggan dan akhirnya berimbas pada peningkatan penjualan. Peningkatan penjualan dapat memberikan keuntungan yang lebih tinggi (Pearce, 2013). Keuntungan tersebut dapat membantu pengusaha mikro meningkatkan modalnya, tenaga kerja serta volume usahanya sehingga dengan memperbaiki system pemasaran diharapkan dapat menyelesaikan masalahmasalah lainnya yang dihadapi oleh kedua mitra dalam pengusulan kegiatan PKM. 
Dedy Harto, Sulistya Rini Pratiwi, Mohamad Nur Utomo, Meylin Rahmawati Penerapan Internet Marketing Dalam Meningkatkan Pendapatan Pada UMKM
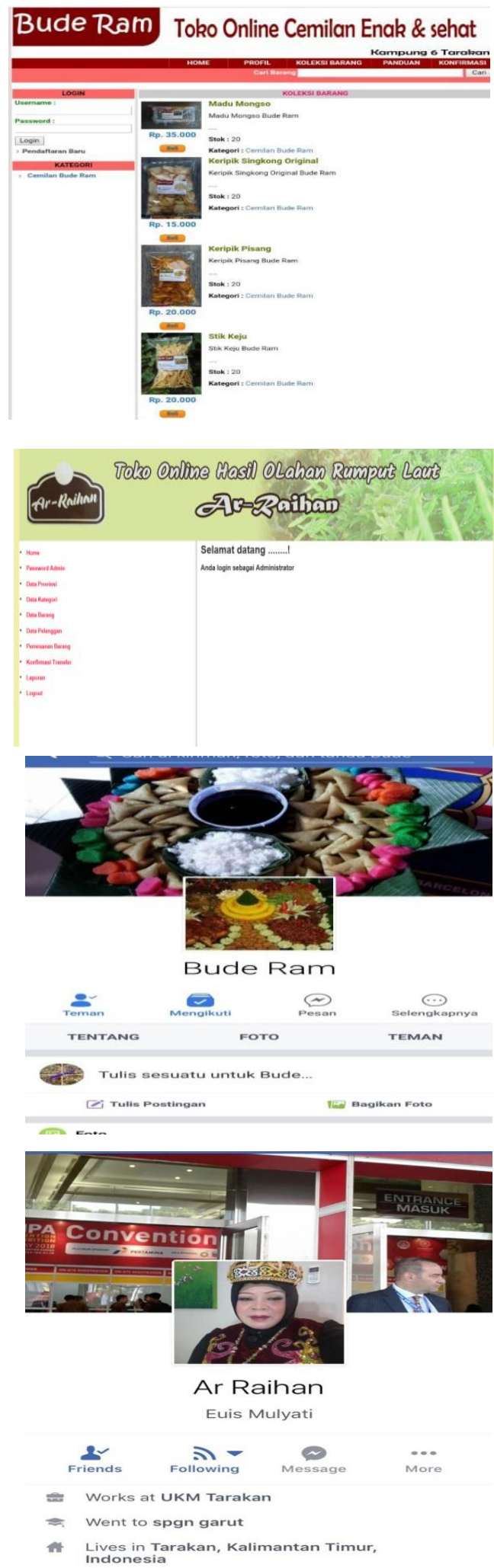

Gambar 1. Website dan Sosial Media Mitra

\section{SIMPULAN}

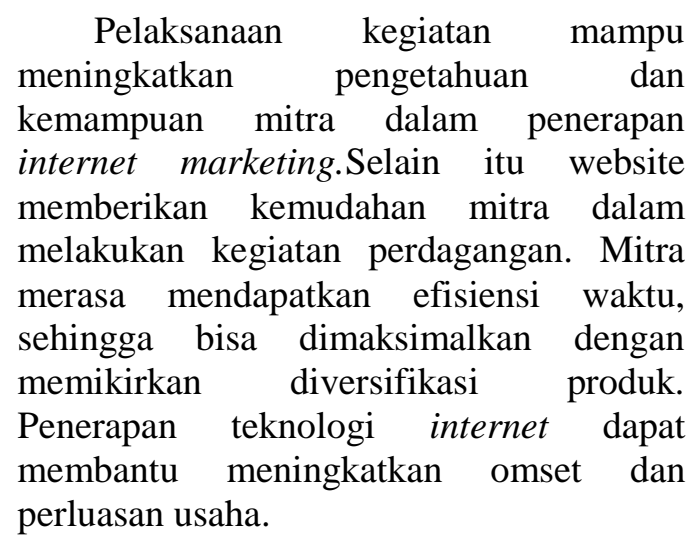

\section{UCAPAN TERIMAKASIH}

Program pengabdian yang dilaksanakan merupakan skema pengabdian Program Kemitraan Masyarakat (PKM), tim pengabdian mengucapkan terimakasih kepada Ristekdikti, yang telah mendanai pelaksanaan program pengabdian kepada masyarakat, Lembaga Penelitian dan Pengabdian Kepada Masyarakat (LPPM) Universitas Borneo Tarakan (UBT) yang telah mengkoordinir pelaksanaan kegiatan pengabdian masyarakat, UKM Bude Ram dan UKM Ar-Raihan, sebagai mitra dalam program PKM, dan telah secara aktif ikut berpartisipasi dalam program pengabdian ini

\section{DAFTAR PUSTAKA}

Datta, Palto R.et.al. (2005). Viral Marketing: New Form of Word-ofMouth through Internet. The Business Review, 3(2)

Kosasi, S. (2014). Pembuatan Sistem Informasi Penjualan Berbasis Web Untuk Memperluas Pangsa Pasar. Prosiding SNATIF Ke-1 Tahun 2014. Fakultas Teknik - Universitas Muria Kudus, 225-232.

Kotler, P., dan K. L. College.(2009). Manajemen Pemasaran (Edisi Bahasa 
Indonesia). E. K. B. J. 1. Indonesia: Indeks.

Kuncoro, M. (2007). Ekonomi Industri Indonesia: Menuju Negara Industri Baru 2030. Yogyakarta: Andi.

Kuncoro, M., dan A. Abimamyu. (1995). Struktur Dan Kinerja Industry Indonesia Dalam Era Deregulasi Dan Debirokratisasi. Kelola (Gadjah Mada University Business Review), 4 (10).

Mujiyana, L. Sularto, dan M. A. Mukhyi. (2012). Pengaruh Penerapan Periklanan DI Internet dan Pemasaran Melalui E-mail Produk UMKM dI Wilayah Depok. Jurnal TI Undip, 7 (3),161-168.

Pearce, J.A., Robinson, R.B. (2013). Strategic Management : Formulation, Implementation, and Control Manajemen Strategis (12th ed $)$. Jakarta: Salemba Empat

Reimers, V., C. W. Chao, dan S. Gorman. (2016). Permission email marketing and its influence on online shopping. Asia Pacific Journal of Marketing and Logistics, 28 (2), 308 -322.

Sagan, C., \& Leighton, T. 2010. The Internet and The Future of News. American Study of Arts and Sciences 139 (2), 119-125.

Sudaryanto, dan A. Hanim. (2002). Evaluasi Kesiapan UKM Menyongsong Pasar Bebas Asean (AFTA) : Analisis Perspektif dan Tinjauan Teoritis. Jurnal Ekonomi Akuntansi dan Manajemen, 1 (2).

Supriyanto. (2004). Pemberdayaan Teknologi Informasi untuk Keunggulan Bisnis. Jurnal Ekonomi \& Pendidikan, 2 (1), 99-112.

Yulianto, A. (2015). Kajian Internet Marketing Sebagai Salah Satu Media Pemasaran Industri Perhotelan. Jurnal Khasanah Ilmu, 6 (1), 65-78. 